\title{
Bank Lending Channel in Transmission of Monetary Policy in Japan, 2000-2012: Bayesian Estimation Analysis
}

\author{
Masao Kumamoto ${ }^{1}$ \& Juanjuan Zhuo $^{2}$ \\ ${ }^{1}$ Department of Economics, Tokyo Keizai University, Tokyo, Japan. \\ ${ }^{2}$ Graduate School of Economics, ,Tokyo Keizai University, Tokyo, Japan. \\ Correspondence: Masao Kumamoto, Department of Economics, Tokyo Keizai University, 1-7-34, Minami-cho, \\ Kokubunji-shi, Tokyo, 185-8502, Japan.
}

Received: October 22, 2015

Accepted: November 4, $2015 \quad$ Available online: November 12, 2015

doi:10.11114/aef.v2i4.1198

URL: http://dx.doi.org/10.11114/aef.v2i4.1198

\begin{abstract}
This paper investigates empirically whether a bank lending channel of monetary policy existed in Japan from 2000 to 2012. We extend Bernanke and Blinder's model and estimate it with the Bayesian method to deal with the identification problem. In particular, we focus on the differential effects of quantitative easing monetary policy regardless of bank size (City banks vs. Regional banks) and firm size (all enterprises vs. small and medium-sized enterprises). We find that the semi-elasticities of loan supply with respect to bank lending rate are larger than those of loan demand, implying a need for larger decline in bank lending rate to stimulate loan demand following an increase in loan supply. We also find that the semi-elasticities of both loan demand and loan supply are almost the same with respect to bank lending rate regardless of bank and enterprise size. Bayesian impulse response function analyses show an increase in bank lending but a decline in spread following quantitative easing monetary policy shock, which is evidence of the bank lending channel. Variance decomposition analyses show that while a large proportion of forecast error variance in bank loans is explained by monetary policy shock, a large proportion of forecast error variance in spread is explained by loan supply shocks. These results also comprise evidence of bank lending channel. However, we find no evidence that loans of smaller banks and loans to smaller firms are more sensitive to monetary policy.
\end{abstract}

Keywords: monetary policy, bank lending channel, Bayesian estimation, Japan

\section{Introduction}

Since the leading work of Bernanke and Blinder (1988), many studies have examined the role of banks in the monetary policy transmission mechanism. Banks play two key roles in the transmission. One is the money role, or the interest rate channel, by which banks act on the liability side; that is, they create money by issuing deposits. The other is the credit role, or the bank lending channel, by which they act on the assets side.

According to Bernanke and Blinder (1988), Kashyap and Stein (1994), and Benanke and Gertler (1995), the bank lending channel stems from credit market imperfections, mainly asymmetric information. In case of information asymmetries, monetary policy has a direct effect on the external finance premium, which becomes a "wedge" in costs between funds raised externally (by issuing equity or debt) and the funds generated internally (by retaining earnings). For example, following contractionary monetary policy, banks' reserves decrease, and, because their ability to issue deposits is constrained following the reserve requirements, their deposits also decrease. If the banks cannot insulate their lending activities from changes in reserves by either switching from deposits to other forms of finance such as CDs, CPs, and equity or by adjusting their net holdings of bonds, they would have to reduce their supply of bank loans. On the other hand, if some firms are bank-dependent and therefore cannot offset the decline in bank loan supply by switching their form of external finance by issuing corporate bonds or equities, their investment would fall and, hence, the aggregate demand would fall. (Note 1)

A conventional Investment Saving-Liquidity Preference Money Supply (IS-LM) model has two financial assets, money and bonds. Since money is assumed to pay a zero nominal interest rate, the determined nominal interest rate is interpreted as returns on bonds. Bernanke and Blinder (1988) introduce the loan market into the IS-LM framework by distinguishing between money, bonds, and bank loans. They assume that (i) deposits and other sources of finance are not perfect substitutes for banks, so that banks are unable to insulate their loan supply from the decline in bank reserves 
induced by monetary policy; (ii) bank loans and other sources of finance are not perfect substitutes for firms, so that firms are unable to insulate their investments from a decline in bank loan supply; and (iii) aggregate demand depends on both bank lending rate and bond rate. The prominent feature of the model is that the modified IS curve, derived by combining the commodity market clearing condition and the credit market clearing condition and thus called "the CC curve," depends on the volume of reserves. Thus, a change in reserves following monetary policy affects not only the LM curve but also the modified IS curve.

The objective of this paper is to investigate empirically whether the bank lending channel operated in Japan. Following the burst of the asset price bubbles in the early 1990s, the Japanese economy went into a long economic slump. The failure of large financial institutions in autumn 1997 forced the Bank of Japan (BOJ) to lower the overnight call rate to 0.02\% in February 1999. The period from 1999 to 2000 is called the "zero interest rate period" in Japan, and the BOJ no longer had room for further decline in the nominal interest rate. In March 2002, the BOJ decided to adopt a new framework, under which it could control its outstanding current account balances as the main operating instrument, and it raised the target level of the current account balance. (Note 2) However, as Krugman (1998a, 1998b) argued, Japan might have been in a liquidity trap in which the semi-elasticity of money demand to interest rate becomes so high that the quantitative easing monetary policy is ineffective in lowering the interest rates and stimulating the economy. However, note that this argument is based on the conventional IS-LM framework wherein the quantitative easing monetary policy could affect only the LM curve. On the other hand, if the bank lending channel can operate in Japan, the quantitative easing monetary policy can have some positive effect on the output. Therefore, to assess the BOJ's quantitative easing monetary policy, we need to investigate whether the bank lending channel existed in Japan.

In this paper, we follow Bernanke and Blinder (1988) and propose a simple model with a bank lending channel. We then estimate the model using the Bayesian method to investigate whether the bank lending channel existed in Japan. We know that empirical analysis based on aggregate data suffer from an important identification problem: the inability to distinguish the change in bank loan observed after monetary policy is attributed to a change in loan supply (bank lending channel) or to a change in demand for bank loans stemming from a change in investments. The Bayesian estimation method allows us to distinguish the structural shocks that enable us to deal with the identification problem. Moreover, we focus on the differential quantitative easing monetary policy effects regardless of bank and firm size. This is motivated by Kashyap and Stein's (1994) finding that since the existence of bank lending channels depends on the assumption of credit market imperfections from mainly information asymmetries, the loans of smaller banks and loans to bank-dependent smaller firms are more sensitive to monetary policy.

The remainder of this paper is organized as follows. Section 2 overviews the related literature that empirically investigates the bank lending channel in the monetary policy transmission mechanism. Section 3 proposes a simple dynamic stochastic general equilibrium (DSGE) model, in line with Bernanke and Blinder (1988), and considers the bank lending channel. Section 4 estimates the model using the Bayesian estimation method, and Section 5 concludes the study.

\section{Literature Review}

A vast body of the literature has investigated the bank lending channel of monetary policy empirically. Table 1 summarizes the related literature.

A large number of the early empirical works using aggregate data depend on vector autoregressive (VAR)-type models. They study the role of banks in the monetary policy transmission mechanism by investigating how bank loans respond to changes in monetary policy instruments or by examining the predictive power of bank loans for real economic variables. These studies include Bernanke and Blinder (1992), Ueda (1993), Dale and Halden (1993) and Walsh and Wilcox (1995). However, studies based on reduced-form VAR models suffer from an identification problem: the inability to distinguish between the change in bank loans following a monetary-policy induced change in loan supply (bank lending channel) and the change in demand for bank loans following a change in investments (interest rate channel).

There are mainly four approaches to deal with this identification problem.

The first employs a structural VAR (SVAR) model to distinguish between structural shocks, including loan supply shocks and loan demand shocks. Fackler (1990), Fackler and Rogers (1993), and Holtemöller (2003) are studies classified under this approach. 
Table 1. Literature review

\begin{tabular}{|c|c|c|c|c|}
\hline author & $\begin{array}{c}\text { countries } \\
\text { sample periods / frequaency }\end{array}$ & $\begin{array}{l}\text { estimation methods } \\
\text { (prominent features) }\end{array}$ & variables & findings \\
\hline Bernanke and Blinder (1988) & $\begin{array}{c}\text { USA } \\
\text { 1974Q1-1985Q4 / quarterly }\end{array}$ & instrumental variables (IV) & $\begin{array}{l}\text { money demand function : } m \text { on } m_{-1}, i, p, y \\
\text { loan demand function } l \text { on } l_{-1}, \rho, i, p, y\end{array}$ & $\begin{array}{l}\text { Money demand shocks became much more important } \\
\text { relative to credit demand shocks in the } 1980 \text { 's. }\end{array}$ \\
\hline Romer and Romer (1990) & $\begin{array}{c}\text { USA } \\
\text { 1941M 1-1984M 12/monthly }\end{array}$ & OLS,2SLS,IV & $\begin{array}{l}\text { "St.Loius equation" } \\
\Delta y \text { on lagged } \Delta y, \text { lagged } \Delta m, \text { dummy } \\
\Delta y \text { on lagged } \Delta y, \text { lagged } \Delta l, \text { dummy }\end{array}$ & $\begin{array}{l}\text { Examing the dates of shifts to anti-inflationary policy } \\
\text { (Romer dates). The forecast errors of credit supply is } \\
\text { smaller than that of money supply, which implies that } \\
\text { monetary policy inflences over the economy through } \\
\text { money channel rather than through credit channel. }\end{array}$ \\
\hline Fackler (1990) & $\begin{array}{c}\text { USA } \\
\text { 1960Q1-1984Q4 / quarterly }\end{array}$ & SVAR & $\begin{array}{l}\text { real military spending, } m b, m, p, i, y \text {, federal and } \\
\text { private components of total nonfinancial domestic } \\
\text { debt }\end{array}$ & $\begin{array}{l}\text { The federal and private components of total credit } \\
\text { individually have important but different effects on } \\
\text { economic activity }\end{array}$ \\
\hline Bernanke and Blinder (1992) & $\begin{array}{c}\text { USA } \\
\text { 1959M 7-1989M 12/monthly }\end{array}$ & VAR & $\begin{array}{l}p, \ln (\mathrm{M} 1), \ln (\mathrm{M} 2), i \quad(\mathrm{FF} \text { rate, } \mathrm{TB} \text { rate, bond rate), } \\
\text { nonborrowed reserves of depository institutions }\end{array}$ & $\begin{array}{l}\text { Nominal interest rates, particulary FF rate, are good } \\
\text { forcasts of real variables. Monetary policy works in part } \\
\text { by affecting the composition of bank assets. }\end{array}$ \\
\hline Fackler and Rogers (1993) & $\begin{array}{c}\text { USA } \\
\text { 1973Q2-1989Q1 / quarterly }\end{array}$ & $\begin{array}{c}\text { SVAR } \\
\text { (considering exchage rate channel) }\end{array}$ & $\begin{array}{l}\text { government expenditures, } p, e x, m, \text { total } \\
\text { nonfinancial domestic debt, } y, \mathrm{i}\end{array}$ & $\begin{array}{l}\text { Credit is at least as important as any other variable in } \\
\text { explaining movements in output, prices and interest rate. } \\
\text { Movements in exchange rate have significant effects on } \\
\text { domestic credit. These rusults supprts the creit view and } \\
\text { indicates the importance of the international features of the } \\
\text { model. }\end{array}$ \\
\hline Gertler and Gilchrist (1993) & $\begin{array}{c}\text { USA } \\
\text { 1975Q1-1991Q4 / quarterly }\end{array}$ & $\begin{array}{c}\text { VAR } \\
\text { (considering firm size) }\end{array}$ & $\begin{array}{l}y, \pi, \quad i \text { financial variable (total loans, business } \\
\text { loans, total securities, real estate loans, large time } \\
\text { deposits, consumer loan, N.E.C. bank loans, CP, } \\
\text { tradable pay ables, tradable recievable) }\end{array}$ & $\begin{array}{l}\text { Following contractionary monetary policy, lending to } \\
\text { small firms declines relative to lending to large firms, and } \\
\text { short term borrowing by large firms from both banks and } \\
\text { nonbank sources rise substantially. }\end{array}$ \\
\hline Kashyap, Stein and Wilcox (1993) & $\begin{array}{c}\text { USA } \\
\text { 1963Q1-1989Q4 / quarterly }\end{array}$ & $\begin{array}{l}\text { Three types of investment functions } \\
\text { VAR }\end{array}$ & $\begin{array}{l}\text { "mix", spread (CP rate - TB rate), investment and } \\
\text { inventory variables, business cycle indicator }\end{array}$ & $\begin{array}{l}\text { Shifts in monetary policy alters the mix of loans and } \mathrm{CP} \text {, } \\
\text { and the induced shifts in this mix affects investment. }\end{array}$ \\
\hline Ramey (1993) & $\begin{array}{c}\text { USA } \\
\text { 1954M 1-1991M 12 / monthly }\end{array}$ & VECM & $\begin{array}{l}y \text { (industrial production), } \ln (\mathrm{M} 1), \ln (\mathrm{M} 2), l, \\
\text { inventory, p, i(FF rate, TB rate, CP rate), } \\
\text { monetary policy index(Boshen and Mill(1992)) }\end{array}$ & $\begin{array}{l}\text { The predivtive power of } \mathrm{M} 2 \text { for output is stronger than } \\
\text { that of bank loan, which suggests that the money channel } \\
\text { is much more important than the credit channel. }\end{array}$ \\
\hline Ueda(1993) & $\begin{array}{c}\text { Japan } \\
\text { 1969M 1-1989M 10/monthly }\end{array}$ & VAR & $m b, m(\mathrm{M} 1, \mathrm{M} 2), l, y, p, i$ & $\begin{array}{l}\text { Among various monetary variables, bank loan is the best } \\
\text { predictor of real economic variables, which means that } \\
\text { bank loans play an important role in the transmission of } \\
\text { monetary policy }\end{array}$ \\
\hline Dale and Halden (1994) & $\begin{array}{c}\text { UK } \\
\text { 1974M6-1992M 10/monthly }\end{array}$ & $\begin{array}{c}\text { VAR } \\
\begin{array}{c}\text { (considering personal and company } \\
\text { sectors separately) }\end{array} \\
\end{array}$ & $\begin{array}{l}y \text { (industrial production),retail sales, } l, d, e x, \text { stock } \\
\text { price }\end{array}$ & $\begin{array}{l}\text { Bank behavior plays important role in monetary policy } \\
\text { transmission mechanism, but the importance of banks } \\
\text { varies across sectors }\end{array}$ \\
\hline Gertler and Gilchrist (1994) & $\begin{array}{c}\text { USA } \\
\text { 1960Q1-1991Q4 / quarterly }\end{array}$ & $\begin{array}{c}\text { VAR } \\
\text { (considering firm size) }\end{array}$ & sales, inventories, short-tem debt & $\begin{array}{l}\text { Following contractionary monetary policy, small firms } \\
\text { contract substantially relative to large firms and they } \\
\text { account for a significantly disproportionate amount of the } \\
\text { ensuing decline in manufacturing. }\end{array}$ \\
\hline Miron, Romer and Weil (1994) & $\begin{array}{c}\text { USA } \\
\text { 1890-1991 }\end{array}$ & $\begin{array}{l}\text { event study } \\
\text { OLS }\end{array}$ & $\begin{array}{l}\text { monetary contraction } \rightarrow \operatorname{spread}(\rho-i) \text {, mix } \\
y \text { (industrial production) on } l\end{array}$ & $\begin{array}{l}\text { The evidence of the systematic changes in the importance } \\
\text { of the lending channel cannot be found given the changes in } \\
\text { financial structure. }\end{array}$ \\
\hline Oliner and Rudebusch (1995) & $\begin{array}{c}\text { USA } \\
\text { 1973Q4-1991Q2 / quarterly }\end{array}$ & $\begin{array}{c}\text { OLS } \\
\text { (considering firm size) }\end{array}$ & mix (three types) on lagged mix, monetary policy i & $\begin{array}{l}\text { Small and large firms bank debt behaves little differently } \\
\text { from nonbank debt after monetary policy shock. There is } \\
\text { no evidence that contractionary monetary policy limits the } \\
\text { supply of bank debt relative to other forms of finance }\end{array}$ \\
\hline Peek and Rosengren (1995) & $\begin{array}{l}\text { USA（New England9 } \\
\text { 1989Q2-1994Q4 / quarterly }\end{array}$ & $\begin{array}{l}\text { OLS, 2SLS } \\
\begin{array}{l}\text { (considering regulatory policy on the } \\
\text { banking sector) }\end{array}\end{array}$ & $\Delta l$ on lagged $i$, lagged equity capital & $\begin{array}{l}\text { Monetary policy effects through capital- unconstrained } \\
\text { banks have a stronger effect on the economy compared to } \\
\text { the effects through capital-constrained banks }\end{array}$ \\
\hline Oliner and Rudebusch (1996) & $\begin{array}{c}\text { USA } \\
\text { 1962Q2-1992Q4 / quarterly }\end{array}$ & $\begin{array}{c}\text { OLS } \\
\text { (considering firm size) }\end{array}$ & $\begin{array}{l}\text { Investment function: Investment on lagged } \\
\text { Investment, lagged net sales, lagged cost of capital, } \\
\text { cash flow-1, }\end{array}$ & $\begin{array}{l}\text { For small firms, external finance becomes scarce and then } \\
\text { linkage between internal funds and investment tightens } \\
\text { significantly after contractionary monetary policy. }\end{array}$ \\
\hline Walsh and Wilcox (1995) & $\begin{array}{c}\text { USA } \\
\text { 1959M 1-1994M 12/monthly }\end{array}$ & VAR & $y, \Delta p, \mathrm{FF}$ rate, prime rate, $l$ & $\begin{array}{l}\text { Shocks to loan supply are sometimes important } \\
\text { determinants of the volume of bank loan outstanding and } \\
\text { of aggregate output. }\end{array}$ \\
\hline Kakes (2000) & $\begin{array}{c}\text { Netherlands } \\
\text { 1979Q1-1993Q4 / quarterly }\end{array}$ & VECM & $\begin{array}{l}\rho, \text { long-term interest rate, } y \text {, bank's bond holdings, } \\
l\end{array}$ & $\begin{array}{l}\text { Banks use bonds as a buffer stock to offset exogenous } \\
\text { disturbenace, thus bank lending is not an important } \\
\text { transmission mechanism of monetary policy. }\end{array}$ \\
\hline Holtemöller (2003) & $\begin{array}{c}\text { Germany } \\
\text { 1975M 1-1998M 12/monthly }\end{array}$ & SVAR & $\begin{array}{l}\text { world export price, } y \text { (industrial production), } p, \text { i, } \\
\operatorname{spread}(\rho-i), l, \text { real effective exchange rate }\end{array}$ & $\begin{array}{l}\text { The impact of monetary policy on output can be } \\
\text { explained cinsiderable extent by credit channel. } \\
\text { Contractionary monetary policy increases the loan spread } \\
\text { (external finance premium) }\end{array}$ \\
\hline Chiades and Gambacorta (2004) & $\begin{array}{c}\text { Italy } \\
\text { 1984M 1-1998M } 12 \text { / monthly }\end{array}$ & SVECM & $\begin{array}{l}y \text { (industrial production) }), p, i \text {, ex, spread }(\rho-i) \text {, } \\
\text { wage index, } p^{*}(\text { Germany }), i *(\text { Germany }) \text {, worl } \\
\text { price commodity index }\end{array}$ & $\begin{array}{l}\text { The impact of monetary policy on output and prices is } \\
\text { significant through the money and credit channels, while } \\
\text { exchange rate puzzle is detected. }\end{array}$ \\
\hline Hülsewig, Winker and Worms (2004) & $\begin{array}{c}\text { Germany } \\
\text { 1975Q1-1998Q4 / quarterly }\end{array}$ & SVECM & $\begin{array}{l}l, \text { bank's equity, } y, \pi, i \text { (bond rate, money market } \\
\text { rate) }\end{array}$ & $\begin{array}{l}\text { There exists long-run loan demand and loan supply, which } \\
\text { is the evidence in support of the bank lending channel. } \\
\text { Although monetary policy induced changes in loan supply } \\
\text { are significant, but they are small in magnitude. }\end{array}$ \\
\hline Ford, Agung, Ahmed and Santoso (2003) & $\begin{array}{c}\text { Japan } \\
\text { 1965M 1-1999M 6 / monthly }\end{array}$ & $\begin{array}{c}\text { SVAR } \\
\text { (considering bank and firm size) }\end{array}$ & $\begin{array}{l}i \text {, stock index, bank's balance sheet varables ( } d \text {, } \\
\text { securities, l), } y \text { (industrial production), } p\end{array}$ & $\begin{array}{l}\text { The contractionary monetary policy influences more } \\
\text { substantially small banks and small bisunesses, groups } \\
\text { that are more severely affected by capital market } \\
\text { imperfections. }\end{array}$ \\
\hline Brissmis and Magginas (2005) & $\begin{array}{l}\text { USA, Gernamy, Japan, France, UK, Italy } \\
\text { 1977Q1-1999Q4(-1998Q4 for Germany, France and } \\
\text { Italy)/ quarterly }\end{array}$ & (comp aring 6 countries) & $y, p, l, d, \operatorname{spread}(\rho-i)$ & $\begin{array}{l}\text { In the USA and UK, the lending channel is not a part of } \\
\text { the transmission mechanism, while it plays a significant } \\
\text { role in japan. The other three European are in between. } \\
\text { Changes in financial structures matter for monetary policy } \\
\text { transmission. }\end{array}$ \\
\hline
\end{tabular}


Notes: $y$ : output; $p$ : price index; $i$ : short-term nominal interest rate; $\rho$ : bank lending rate; $m b$ : monetary base; $m$ : money supply; $l$ : bank loans; $d$ : deposit; ex: nominal exchange rate.

The second approach employs cointegration methods, or the vector error correction model (VECM). As mentioned earlier, three conditions must be satisfied for a bank lending channel to exist: (i) bank loans must be imperfect substitutes for other sources of finance, (ii) no perfect substitutes must exist for other sources of bank portfolios, and (iii) the aggregate loan demand must depend on the bank lending rate. Therefore, this approach investigates the stable long-run relationships between (i) loan demand and bank lending rate in the loan demand function, (ii) loan supply and bank lending rate in the loan supply function, and (iii) the aggregate demand and bank lending rate in the aggregate demand function. Examples of this approach include Kakes (2000), Chiades and Gambacorta (2004), Hülsewig, Winker, and Worms (2004), and Brissimis and Magginas (2005).

The third approach focuses on the relative movements of bank loans and a substitute for bank loans, commercial papers (CPs). The central insight is that they should contain information about the loan demand. Following a contractionary monetary policy, for example, if bank loans decrease due to a decline in loan supply, firms will increase their issuance of CPs. On the other hand, if a decline in loan demand is the main reason for the decrease in bank loans, the issuance of CPs also would decrease. Kashyap, Stein, and Wilcox (1993) use the "mix" variables, defined as ratio of bank loans to the sum of bank loans and CPs, for analysis. They investigate whether the mix variables would decrease significantly following a contractionary monetary policy and examine the predictive power of the mix variables for real economic variables. Miron, Romer, and Weil (1994) and Oliner and Rudebusch (1996) are also classified under this approach.

The fourth approach uses disaggregate rather than aggregate data and examines the differential effects of monetary policy regardless of bank and firm size. As for bank size, Kashyap and Stein $(1995,2000)$ show that small-bank lending falls substantially compared to large-bank lending following a tight monetary policy, and show that the bank lending channel matters more for the lending of small banks with the least liquid balance sheets. These results cannot be explained using the traditional interest rate channel. As for firm size, Gertler and Gilchrist $(1993,1994)$ find that small firms contract substantial sales and short-term debts (bank loans and CPs) relative to large firms after a contractionary monetary policy. These asymmetric responses between small and large firms cannot be explained using the traditional interest rate channel. Thus, the credit channel has larger effects on small firms that depend on banks and have higher agency costs, indicating that credit market imperfections help propagate the impact of monetary policy. Studies based on this approach include Oliner and Rudebusch (1995, 1996), Peek and Rosengren (1995), and Ford Agung, Ahmed, and Santoso (2003). In recent years, some approaches use micro-data (individual bank data or firm data); for example, Ehrmann, Gambacorta, Martínez-Pagés, Sevestre, and Worms (2003).

This paper presents another empirical approach to deal with the identification problem, the Bayesian estimation method. This system-based method estimates each equation simultaneously and allows us to identify each structural shock, including the loan supply and loan demand shocks. The SVAR approach also can estimate each equation simultaneously and identify each structural shock. However, since the SVAR is based on a non-linear estimation method, implausible parameter values are often estimated, depending on their initial values. On the other hand, the Bayesian method can incorporate additional parameter information through priors and hence can offer economically meaningful parameters.

\section{Model}

In this section, we follow Bernanke and Blinder (1988) and propose a simple model that uses the bank lending channel.

As in Bernanke and Blinder (1988), we assume three assets, money, bonds, and bank loans. Bernanke and Blinder (1988) focus on how monetary policy affects the aggregate demand, and so they ignore the supply side and treat the price level as given. We deviate from Bernanke and Blinder (1988) and endogenize the price level (inflation rate) by adding the aggregate supply curve (the Phillips curve) to their model. Hereafter, the lowercase letter denotes the percentage deviation from its steady-state value, except for interest rate.

We describe the loan market by the following equations:

$$
\begin{gathered}
l_{t}^{d}-p_{t}=a_{1} y_{t}-a_{2} \rho_{t}+\varepsilon_{l d, t}, \quad a_{1}, a_{2}>0 \\
l_{t}^{s}=b_{1}\left(\rho_{t}-i_{t}\right)+d_{t}+\varepsilon_{l s, t}, \quad b_{1}>0
\end{gathered}
$$

where $l^{d}$ and $l^{s}$ denote the loan demand and loan supply, respectively; $y$ is the real output; $p$ is the price level; $\rho$ and $i$ are the bank lending rate and bond rate, respectively; and $d$ denotes deposits. Equation (1) is a loan demand function, by which the real loan demand is increasing in economic activity but decreasing in bank lending rate. Loan demand will not depend on the bond rate if the firms are bank-dependent, that is, if they cannot issue corporate bonds to finance their expenditure. Equation (2) is a loan supply function, by which the fraction of the bank's net of 
required reserves held in bank loans is increasing in the interest rate spread $\rho-i$. (Note 3$) \varepsilon_{l d}$ and $\varepsilon_{l s}$ are exogenous shocks to loan demand and loan supply, respectively.

Since the bank's reserve demand equals its reserve supply determined by the central bank in equilibrium, the equilibrium reserves condition can be written as

$$
r s_{t}^{s}=-c_{1} i_{t}+d_{t}, \quad b_{1}>c_{1}>0,
$$

where the left-hand side of equation (3) $\left(r s^{s}\right)$ is the reserve supply and the right-hand side indicates that the reserve demand is decreasing in bond rate. (Note 4 )

By inserting equation (3) into (2) and eliminating $d$, we obtain the loan supply function, represented in terms of the reserve supply $r s$ as follows:

$$
l_{t}^{s}=b_{1} \rho_{t}-\left(b_{1}-c_{1}\right) i_{t}+r s_{t}^{s}+\varepsilon_{l s, t}
$$

We find that the assumption of $b_{1}>c_{1}$ ensures that the loan supply is decreasing in the bond rate, $i$.

The money market clearing condition can be described by a traditional LM curve,

$$
d_{t}-p_{t}=d_{1} y_{t}-d_{2} i_{t}+\varepsilon_{d d, t}, d_{1}, d_{2}>0 .
$$

The demand for deposits (i.e., money) is increasing in real income $y$ and decreasing in the opportunity cost of holding deposits $i$. (Note 5) $\varepsilon_{d d}$ is the exogenous shock to deposit (money) demand. By inserting equation (3) into (5) and eliminating $d$, we obtain the LM curve, represented in terms of the reserve supply $r s$ as follows:

$$
r s_{t}-p_{t}=d_{1} y_{t}-\left(c_{1}+d_{2}\right) i_{t}+\varepsilon_{d d, t} .
$$

We specify the IS curve as

$$
y_{t}=e_{1} y_{t-1}-e_{2}\left\{i_{t}-\left(E_{t}\left[p_{t+1}\right]-p_{t}\right)\right\}-e_{3}\left\{\rho_{t}-\left(E_{t}\left[p_{t+1}\right]-p_{t}\right)\right\}+\varepsilon_{y, t}, e_{1}, e_{2}, e_{3}>0,
$$

which indicates that the aggregate demand depends negatively on the real interest rate measured by the bond rate as well as bank lending rate. We also include the aggregate demand lag term $y_{-1}$ to capture the habit formation in consumption and the adjustment costs in investment. $\varepsilon_{y}$ denotes the demand shock.

The Phillips curve (the aggregate supply curve) is specified as

$$
\pi_{t}=g_{1} \pi_{t-1}+g_{2} y_{t}+\varepsilon_{\pi, t}, g_{1}, g_{2}>0 .
$$

We include a lag term $\pi_{-1}$ to capture inflation persistence, that is, the dependence of inflation on its own past. $\varepsilon_{\pi}$ denotes cost-push shock. The specification in equation (8) is based on Galí and Gertler (1999) and Christiano, Eichenbaum, and Evans (2005) that point out that the existence of backward-looking firms, which use a simple rule-of-thumb or an indexation when setting their prices, creates inflation persistence.

By plugging the loan market clearing condition [combining equations (1) and (4) into (7)] so as to eliminate $\rho$, we obtain

$$
\begin{aligned}
& y_{t}=\frac{\left(a_{2}+b_{1}\right) e_{1}}{a_{2}+b_{1}+a_{1} e_{3}} y_{t-1}-\frac{\left(a_{2}+b_{1}\right) e_{2}+\left(b_{1}-c_{1}\right) e_{3}}{a_{2}+b_{1}+a_{1} e_{3}} i_{t}+\frac{\left(a_{2}+b_{1}\right)\left(e_{2}+e_{3}\right)}{a_{2}+b_{1}+a_{1} e_{3}} E_{t}\left[p_{t+1}\right] \\
& \quad-\frac{\left(a_{2}+b_{1}\right) e_{2}+\left(1+a_{2}+b_{1}\right) e_{3}}{a_{2}+b_{1}+a_{1} e_{3}} p_{t}+\frac{e_{3}}{a_{2}+b_{1}+a_{1} e_{3}} r s_{t}^{s}+\frac{e_{3}\left(\varepsilon_{l s, t}-\varepsilon_{l d, t}\right)+\left(a_{2}+b_{1}\right) \varepsilon_{y, t}}{a_{2}+b_{1}+a_{1} e_{3}}
\end{aligned}
$$

Equation (9) is the CC curve, which represents the combination of the real income and bond rate that equilibrate both commodities' (goods) market and the credit market. Under the assumption of $b_{1}>c_{1}>0$, the CC curve is downward sloping in the $y-i$ plane, like the IS curve. As mentioned above, the prominent feature of the CC curve is that it depends on the quantity of reserves, $r s$. Therefore, a change in reserves induced by monetary policy affects not only the LM curve but also the CC curve. We also see from equation (9) that when the loan demand or supply are perfectly elastic with respect to bank lending rate $\left(a_{2}, b_{1} \rightarrow \infty\right)$ or the bank lending rate does not affect the aggregate demand $\left(e_{3}=0\right)$, there is no distinct bank lending channel. 
Our model is closed after specifying the monetary policy rule. Suppose that the monetary policy operating instrument is the reserve supply (the outstanding current account balance at the BOJ), consistent with the fact that the BOJ has adopted the reserve supply as the main operating instrument since March 2001. Furthermore, suppose that the BOJ responds to the real income (output gap) and inflation.

$$
\begin{gathered}
r s_{t}^{s}=-h_{1} y_{t}-h_{2} \pi_{t}+v_{t} \\
v_{t}=k_{1} v_{t-1}+\varepsilon_{r s, t}, \quad 0<k_{1}<1
\end{gathered}
$$

Equation (10) indicates that the BOJ decreases the reserve supply when the real output and/or inflation rate increases. Equation (11) indicates that the exogenous component $v$ follows the $\operatorname{AR}(1)$ process. $\varepsilon_{r s}$ is the monetary policy shock.

Summarizing the above, our model consists of seven equations, (1), (4), (6)-(8), (10), and (11), with seven endogenous variables, $x_{t} \equiv\left\{y_{t}, p_{t}, r s_{t}, i_{t}, \rho_{t}, l_{t}, v_{t}\right\}$.

\section{Estimation}

\subsection{Methodology}

We employ the Bayesian methodology to estimate our model. This is a system-based method that allows us to incorporate additional information on parameters through priors. This feature is very useful when only small samples of data are available, as in our model. The Bayesian estimation methodology consists of five steps. (Note 6)

The first step solves the linear rational expectations model. In general, the log-linearized DSGE model can be written as a rational expectations system of the form,

$$
\Gamma_{0}(\Theta) x_{t}=\Gamma_{1}(\Theta) x_{t-1}+\Gamma_{\varepsilon}(\Theta) \varepsilon_{t}+\Gamma_{\eta}(\Theta) \eta_{t},
$$

where $x$ denotes the vector of endogenous variables, $\varepsilon$ is the vector of exogenous process $\eta, E_{t}\left[\eta_{t+1}\right]=0$ denotes the rational expectation forecast errors, and $\Theta$ is the parameter vector. The solution algorithm for the linear rational-expectations model proposed by Sims (2002) is applied to equation (12) to obtain the state transition equation,

$$
x_{t}=\Phi_{1}(\Theta) x_{t-1}+\Phi_{2}(\Theta) \varepsilon_{t} .
$$

At the second step, the model is written in state space form by adding the measurement equation to the state transition equation (13). The measurement equation relates the model variable $x$ to a vector of observables, $z$ :

$$
z_{t}=A(\Theta)+B x_{t}
$$

where $A(\Theta)$ denotes the constant vector, which is related to the parameters, and $B$ denotes the matrix selecting the elements of model variables $x$, which are related to the observable variables.

The third step is the likelihood function $L(\Theta \mid Z)$, where $Z=\left\{z_{t}\right\}_{t=1}^{T}$ is evaluated with the Kalman filter. However, estimating parameter vector $\Theta$ using the maximum-likelihood method is not easy, because the likelihood function is specified as a complex multi-dimensional parameter function and might have twin or multiple peaks, or a flatter shape around its peak.

Thus, at the fourth step, the likelihood function $L(\Theta \mid Z)$ and prior distribution $p(\Theta)$ are combined to obtain the posterior density function

$$
p(\Theta \mid Z) \propto L(\Theta \mid Z) p(\Theta) .
$$

Now, a numerical optimization routine is used to maximize $\ln L(\Theta \mid Z)+\ln p(\Theta)$ to obtain the posterior mode of $L(\Theta \mid Z) p(\Theta)$, and the inverse of the Hessian of $L(\Theta \mid Z) p(\Theta)$ evaluated at the posterior mode $\Theta=\tilde{\Theta}$, denoted by $\tilde{\Sigma}$, is calculated as

$$
\tilde{\Sigma}=-\left[\left.\frac{\partial^{2} L(\Theta \mid Z) p(\Theta)}{\partial \Theta \partial \Theta^{\prime}}\right|_{\Theta=\tilde{\Theta}}\right]^{-1} .
$$

At the final step, the model derives the parameters' posterior distribution numerically using a Monte Carlo Markov 
Chain (MCMC) algorithm. The specific MCMC algorithm used in this paper is the Metoropolis-Hastings algorithm. In this algorithm, $\Theta^{(0)}$ is drawn from the normal distribution $N\left(\tilde{\Theta}, c_{0}^{2} \tilde{\Sigma}\right)$ as the starting value and $\Theta$ is drawn from the proposal distribution $N\left(\Theta^{(s-1)}, c^{2} \tilde{\Sigma}\right)$ for $s=1, \cdots, n$, where $c>0$ is the scale parameter, which adjusts the variance. The jump from $\Theta^{(s-1)}$ is accepted with probability

$$
\min \left(1, \frac{L(\Theta \mid Z) p(\Theta)}{L\left(\Theta^{(s)} \mid Z\right) p\left(\Theta^{(s-1)}\right)}\right)
$$

and rejected otherwise $\left(\Theta^{(s)}=\Theta^{(s-1)}\right)$. We know that the sequence of $\left\{\Theta^{(1)}, \Theta^{(2)}, \cdots, \Theta^{(n)}\right\}$ converges to the true distribution $L(\Theta \mid Z) p(\Theta)$ as $n \rightarrow \infty$.

In this paper, we generate 100000 draws in this manner, discarding the first 30000 iterations.

\subsection{Data and Priors}

Note that we need at least as many exogenous shocks as there are observed variables to avoid stochastic singularity in Bayesian estimation. Our model includes seven endogenous variables, $x_{t} \equiv\left\{y_{t}, p_{t}, r s_{t}, i_{t}, \rho_{t}, l_{t}, v_{t}\right\}$, and six exogenous shocks, $\varepsilon_{t} \equiv\left\{\varepsilon_{y, t}, \varepsilon_{\pi, t}, \varepsilon_{d d, t}, \varepsilon_{l d, t}, \varepsilon_{l s, t}, \varepsilon_{r s, t}\right\}$. Thus, we can use at most six observable variables. We choose the six observable variables $z_{t} \equiv\left\{y_{t}, p_{t}, r s_{t}, i_{t}, \rho_{t}, l_{t}\right\}$.

Since the sample period should include the era of quantitative easing monetary policy, we set the period from January 2000 to December 2012 using monthly data.

Our model is represented in terms of percentage deviation from its steady-state value, except for the interest rate. Therefore, we log and de-trend the data of the real income (output gap) $y$, price index $p$, bank reserves $r s$, and bank lending $l$ using the Hodrick-Prescott filter with the smoothing parameter of 14400, and de-mean the data on bond rate $i$ and the bank lending rate $\rho$. We calculate the data on $y$ from the industrial production index and on $\pi$ from the consumer price index. As mentioned above, we focus on the differential effects of quantitative easing monetary policy regardless of bank and enterprise size. We consider three categories of Japanese banks based on their size on the lending side: all banks, City banks, and Regional I and II banks (hereafter, Regional banks). (Note 7) We also consider two categories of enterprises based on their borrowing side: all enterprises (corporations), and small and medium-sized enterprises (hereafter SMEs). Thus, the data on bank lending are classified into six categories-(i) $l_{a a}$ : all banks' loans to all firms, (ii) $l_{a s}$ : all banks' loans to SMEs, (iii) $l_{c a}$ : City banks' loans to all enterprises, (iv) $l_{c s}$ : City banks' loans to SMEs, (v) $l_{r a}$ : Regional banks' loans to all firms, and (vi) $l_{r s}$ : Regional banks' loans to SMEs. The data on bond rate $i$ comprise the 10-year government bond yield. As for data on bank lending rate, we categorize three types of data based on the average contract interest rate on loans according to the three categories of banks: the average contract interest rate on loans of all banks for (i) and (ii); that on loans of City banks for (iii) and (iv); and that on loans of Regional banks for (v) and (vi). Owing to limited data availability, we proxy the outstanding balance of the BOJ's current accounts $r s$ as the deposit paid data on the assets side of the banks' balance sheet. Similarly, we use the three types of data on the deposits paid in accordance with the three categories of banks: the deposit paid data of all banks for (i) and (ii); those of City banks for (iii) and (iv); and those of Regional banks for (v) and (vi). The above data can be obtained from the BOJ.

The priors are specified in Table 2, which reports the distribution, the mean, and standard deviations. We use the gamma distribution for parameters restricted to be positive, and the inverse gamma distribution for the standard deviations of the shocks. As for the means of parameters, we choose standard values. 
Table 2. Priors

\begin{tabular}{|c|c|c|c|c|}
\hline & parametres & distribution & mean & standard error \\
\hline$a_{1}$ & elasticity of loan demand with respect to real output & Gamma & 0.5 & 0.1 \\
\hline$a_{2}$ & semi-elasticity of loan demand with respect to bank lending rate & Gamma & 0.02 & 0.004 \\
\hline$b_{1}$ & semi-elasticity of loan supply with respect to spread & Gamma & 0.05 & 0.01 \\
\hline$c_{1}$ & semi-elasticity of bank reserves demand with respect to bond rate & Gamma & 0.01 & 0.002 \\
\hline$d_{1}$ & elasticity of money demand with respect to real output & Gamma & 1.0 & 0.2 \\
\hline$d_{2}$ & semi-elasticity of loan demand with respect to bond rate & Gamma & 0.5 & 0.1 \\
\hline$e_{1}$ & degree of aggregate demand persistence & Gamma & 0.7 & 0.14 \\
\hline$e_{2}$ & $\begin{array}{l}\text { semi-elasticity of aggregate demand with respect to real interest rate } \\
\text { in terms of bond rate }\end{array}$ & Gamma & 1.5 & 0.3 \\
\hline$e_{3}$ & $\begin{array}{l}\text { semi-elasticity of aggregate demand with respect to real interest rate } \\
\text { in terms of bank lending rate }\end{array}$ & Gamma & 1.0 & 0.2 \\
\hline$g_{1}$ & degree of inflation persistence & Gamma & 0.7 & 0.14 \\
\hline$g_{2}$ & elasticity of inflation rate with respect to real output & Gamma & 0.1 & 0.02 \\
\hline$h_{1}$ & coefficient on output gap in the monetary policy reaction function & Gamma & 0.8 & 0.16 \\
\hline$h_{2}$ & coefficient on inflation rate in the monetary policy reaction function & Gamma & 1.2 & 0.24 \\
\hline$k_{1}$ & monetary policy shock persistence & Gamma & 0.7 & 0.14 \\
\hline$\sigma_{y}^{2}$ & variance of demand shock & Inverse Gamma & 0.01 & $(0.009)^{2}$ \\
\hline$\sigma_{\pi^{2}}^{2}$ & variance of cost-push shock & Inverse Gamma & 0.01 & $(0.009)^{2}$ \\
\hline$\sigma_{d d^{2}}$ & variance of money demand shock & Inverse Gamma & 0.01 & $(0.009)^{2}$ \\
\hline$\sigma_{l d^{2}}$ & variance of loan supply shock & Inverse Gamma & 0.01 & $(0.009)^{2}$ \\
\hline$\sigma_{l s^{2}}$ & variance of loan demand shock & Inverse Gamma & 0.01 & $(0.009)^{2}$ \\
\hline$\sigma_{r s^{2}}$ & variance of monetary policy shock & Inverse Gamma & 0.01 & $(0.009)^{2}$ \\
\hline
\end{tabular}

\subsection{Results and Discussions}

Table 3 reports the Bayesian estimation results. As for the loan demand and supply curves, the estimated semi-elasticities of loan supply with respect to bank lending rate are larger than those of loan demand. This means that the loan supply curve is flatter in the $\rho-l$ plane, and, thus, following an increase in loan supply (the loan supply curve shifts to the right), a larger decline in bank lending rate is needed to stimulate loan demand. Furthermore, the semi-elasticities of both loan demand and loan supply with respect to bank lending rate are almost the same regardless of bank and enterprise size. (Note 8) As for the money demand function, the point estimation of semi-elasticities with respect to bond rate $c_{1}+d_{2}$ is about 1.408 , which is much larger than the estimation obtained in previous studies. This might show that Japan has been in a "liquidity trap" in recent years. As for the IS curve, the aggregate demand reacts more to the real interest rate in terms of bank lending rate than in terms of bond rate, meaning that the bank lending rate plays an important role in determining the aggregate demand. As for the Phillips curve, the elasticities of inflation rate with respect to the output gap are estimated at small values of about 0.02 . This means that a $1 \%$ improvement in output gap increases the inflation rate by only $0.02 \%$. These findings are consistent with the fact that the Philipps curve has become "flatter" in recent years. Last, the estimated monetary policy function indicates that the BOJ reacts more aggressively to changes in output gap than to changes in inflation rates.

Figure 1 displays the Bayesian impulse response functions of output gap $y$, inflation rate $\pi$, the spread $\rho-i$, and bank lending $l$ with respect to the one-standard-error positive shock to bank reserves $r s$ for 24 periods (2 years). Table 4 extracts the figures for $\rho-i$ and bank lending $l$. From the figure and table, we find that the quantitative easing monetary policy shock $l$ increases while $\rho-i$ declines, and that $y$ and $\pi$ increase significantly in all cases. The co-existence of the decline in $\rho-i$ and increase in $l$ means that the loan supply increases more than the loan demand, which is evidence of the bank lending channel. Moreover, a comparison of the bank loans to all enterprises with the loans to SMEs shows that the spreads decline more largely, while loans increase more slightly for loans to all enterprises. One possible explanation is that following the quantitative easing monetary policy shock, the loan demand curve of SMEs shifts to the right in larger magnitude.

Table 5 shows the variance decomposition results, that is, the proportion of forecast error variance explained by each shock. We see that the shock that can explain the most proportion in forecast error variance of bank loan $l$ is the monetary policy shock $\varepsilon_{r s}$. On the other hand, the shock that can explain the most proportion in forecast error variance of spread $\rho-i$ is the loan supply shock $\varepsilon_{l s}$. These results are consistent with the impulse response functions and comprise evidence of the bank lending channel. A comparison of the results of loans to all enterprises with those of loans to SMEs also show that a larger proportion in the forecast error variance of bank loan $l$ is explained by loan supply shock $\varepsilon_{l s}$ for loans to SMEs than for loans to all enterprises. These results indicate that the equilibrium 
quantity of bank loans is more constrained by the supply side for loans to SMEs, from, for example, credit rationing. The other noteworthy finding is that a smaller proportion of forecast error variance for Regional bank loans is explained by the monetary policy shock $\varepsilon_{r s}$ whereas a larger proportion is explained by cost-push shock $\varepsilon_{\pi}$. These results are inconsistent with Kashyap and Stein's (1994) findings that the loans of smaller banks as well as the loans to bank-dependent smaller firms are more sensitive to monetary policy.

Table 3. Estimation results

\begin{tabular}{|c|c|c|c|c|c|c|}
\hline & $l_{a a}$ & $l_{a s}$ & $l_{c a}$ & $l_{c s}$ & $l_{r a}$ & $l_{r s}$ \\
\hline \multirow{2}{*}{$a_{1}$} & 0.1115 & 0.1542 & 0.1278 & 0.1961 & 0.1095 & 0.1470 \\
\hline & $(0.0977-0.1270)$ & $(0.1174-0.1900)$ & $(0.0977-0.1544)$ & $(0.1494-0.2408)$ & $(0.0977-0.1228)$ & $(0.1109-0.1801)$ \\
\hline \multirow{2}{*}{$a_{2}$} & 0.0222 & 0.0222 & 0.0222 & 0.0217 & 0.0216 & 0.0223 \\
\hline & $(0.0147-0.0302)$ & $(0.0152-0.0300)$ & $(0.0146-0.0295)$ & $(0.0145-0.0288)$ & $(0.0145-0.0286)$ & $(0.0151-0.0297)$ \\
\hline \multirow{2}{*}{$b_{1}$} & 0.0648 & 0.0643 & 0.0658 & 0.0655 & 0.0630 & 0.0604 \\
\hline & $(0.0451-0.0833)$ & $(0.0428-0.0885)$ & $(0.0435-0.0889)$ & $(0.0448-0.0870)$ & $(0.0452-0.0814)$ & $(0.0414-0.0788)$ \\
\hline \multirow{2}{*}{$c_{1}$} & 0.0111 & 0.0112 & 0.0113 & 0.0116 & 0.0112 & 0.0112 \\
\hline & $(0.0076-0.0147)$ & $(0.0076-0.0146)$ & $(0.0079-0.0150)$ & $(0.0076-0.0155)$ & $(0.0077-0.0147)$ & $(0.0076-0.0147)$ \\
\hline \multirow{2}{*}{$d_{1}$} & 0.7923 & 0.7838 & 0.9227 & 0.9291 & 0.6949 & 0.6857 \\
\hline & (0.5812-1.0014) & $(0.5611-0.9975)$ & $(0.6684-1.1867)$ & $(0.6785-1.1884)$ & $(0.4956-0.9110)$ & $(0.4834-0.8832)$ \\
\hline \multirow{2}{*}{$d_{2}$} & 1.4075 & 1.4082 & 1.4081 & 1.4081 & 1.4078 & 1.4083 \\
\hline & (1.3929-1.4184) & $(1.3947-1.4184)$ & $(1.3946-1.4184)$ & $(1.3950-1.4184)$ & (1.3942-1.4184) & $(1.3948-1.4184)$ \\
\hline \multirow{2}{*}{$e_{1}$} & 0.8450 & 0.8479 & 0.8396 & 0.8402 & 0.8719 & 0.8678 \\
\hline & $(0.7881-0.9041)$ & $(0.7896-0.9055)$ & $(0.7809-0.8991)$ & $(0.7819-0.9002)$ & $(0.8146-0.9289)$ & $(0.8141-0.9238)$ \\
\hline \multirow{2}{*}{$e_{2}$} & 1.0530 & 1.0394 & 1.0372 & 1.0585 & 1.0489 & 1.0175 \\
\hline & $(0.7309-1.3704)$ & $(0.7111-1.3550)$ & $(0.7160-1.3527)$ & $(0.7133-1.3792)$ & $(0.7222-1.3701)$ & $(0.7120-1.3335)$ \\
\hline \multirow{2}{*}{$e_{3}$} & 2.2468 & 2.2485 & 2.2491 & 2.2472 & 2.2488 & 2.2510 \\
\hline & $(2.2165-2.2695)$ & $(2.2208-2.2695)$ & $(2.2228-2.2695)$ & $(2.2173-2.2695)$ & $(2.2217-2.2695)$ & $(2.2286-2.2695)$ \\
\hline \multirow{2}{*}{$g_{1}$} & 0.3069 & 0.3071 & 0.3065 & 0.3067 & 0.3074 & 0.3060 \\
\hline & $(0.2277-0.3857)$ & $(0.2237-0.3859)$ & $(0.2286-0.3842)$ & $(0.2286-0.3879)$ & $(0.2289-0.3846)$ & $(0.2246-0.3863)$ \\
\hline \multirow{2}{*}{$g_{2}$} & 0.0222 & 0.0221 & 0.0219 & 0.0218 & 0.0223 & 0.0225 \\
\hline & $(0.0195-0.0250)$ & $(0.0195-0.0249)$ & $(0.0195-0.0244)$ & $(0.0195-0.0243)$ & $(0.0195-0.0252)$ & $(0.0195-0.0254)$ \\
\hline \multirow{2}{*}{$h_{1}$} & 2.2509 & 2.2522 & 2.2524 & 2.2520 & 2.2523 & 2.2503 \\
\hline & $(2.2255-2.2695)$ & $(2.2301-2.2695)$ & $(2.2302-2.2695)$ & $(2.2288-2.2695)$ & $(2.2297-2.2695)$ & $(2.2260-2.2695)$ \\
\hline \multirow{2}{*}{$h_{2}$} & 1.3014 & 1.2874 & 1.2652 & 1.3049 & 1.3117 & 1.3000 \\
\hline & $(0.8853-1.7042)$ & $(0.8633-1.6781)$ & $(0.8336-1.6842)$ & $(0.8834-1.7185)$ & $(0.8851-1.7193)$ & $(0.8963-1.7096)$ \\
\hline \multirow{2}{*}{$k_{1}$} & 0.7168 & 0.7172 & 0.7347 & 0.7346 & 0.4573 & 0.4589 \\
\hline & $(0.6406-0.7915)$ & $(0.6420-0.7931)$ & $(0.6622-0.8111)$ & $(0.6588-0.8073)$ & $(0.3715-0.5435)$ & $(0.3697-0.5441)$ \\
\hline \multirow{2}{*}{$\sigma_{y}{ }^{2}$} & 0.0251 & 0.0252 & 0.0259 & 0.0259 & 0.0250 & 0.0250 \\
\hline & $(0.0229-0.0274)$ & $(0.0229-0.0274)$ & $(0.0235-0.0282)$ & $(0.0236-0.0282)$ & $(0.0229-0.0271)$ & $(0.0228-0.0272)$ \\
\hline \multirow{2}{*}{$\sigma_{\pi^{2}}^{2}$} & 0.0026 & 0.0026 & 0.0026 & 0.0026 & 0.0026 & 0.0026 \\
\hline & $(0.0023-0.0028)$ & $(0.0024-0.0028)$ & $(0.0023-0.0028)$ & $(0.0023-0.0028)$ & $(0.0023-0.0028)$ & $(0.0023-0.0028)$ \\
\hline \multirow{2}{*}{$\sigma_{d d^{2}}$} & 0.1878 & 0.1886 & 0.2095 & 0.2085 & 0.2114 & 0.2117 \\
\hline & $(0.1717-0.2038)$ & $(0.1714-0.2036)$ & $(0.1909-0.2261)$ & $(0.1910-0.2257)$ & $(0.1944-0.2291)$ & $(0.1940-0.2289)$ \\
\hline \multirow{2}{*}{$\sigma_{I d^{2}}$} & 0.0192 & 0.0197 & 0.0243 & 0.0245 & 0.0170 & 0.0189 \\
\hline & $(0.0175-0.0209)$ & $(0.0179-0.0215)$ & $(0.0220-0.0265)$ & $(0.0222-0.0268)$ & $(0.0155-0.0184)$ & $(0.0172-0.0206)$ \\
\hline \multirow[b]{2}{*}{$\sigma_{l s}{ }^{2}$} & 0.1878 & 0.1860 & 0.2130 & 0.2152 & 0.2052 & 0.2050 \\
\hline & $(0.1727-0.2034)$ & $(0.1713-0.2005)$ & $(0.1942-0.2309)$ & $(0.1960-0.2319)$ & $(0.1866-0.2242)$ & $(0.1876-0.2210)$ \\
\hline \multirow{2}{*}{$\sigma_{r s}{ }^{2}$} & 0.1538 & 0.1534 & 0.1680 & 0.1662 & 0.2096 & 0.2089 \\
\hline & $(0.1404-0.1676)$ & $(0.1417-0.1672)$ & $(0.1543-0.1828)$ & $(0.1523-0.1792)$ & $(0.1916-0.2267)$ & $(0.1902-0.2256)$ \\
\hline
\end{tabular}

Table 4. Impulse response functions of $\rho-i$ and $l$ with respect to $\varepsilon_{r s}$

\begin{tabular}{|c|c|c|c|c|c|c|c|c|c|c|c|c|}
\hline & \multicolumn{2}{|c|}{$l_{a a}$} & \multicolumn{2}{|c|}{$l_{a s}$} & \multicolumn{2}{|c|}{$l_{c a}$} & \multicolumn{2}{|c|}{$l_{c s}$} & \multicolumn{2}{|c|}{$l_{r a}$} & \multicolumn{2}{|c|}{$l_{r s}$} \\
\hline & $\rho-i$ & $l$ & $\rho-i$ & $l$ & $\rho-i$ & $l$ & $\rho-i$ & $l$ & $\rho-i$ & $l$ & $\rho-i$ & $l$ \\
\hline 1 & -0.0658 & 0.0094 & -0.0609 & 0.0113 & -0.0768 & 0.0109 & -0.0686 & 0.0144 & -0.0824 & 0.0126 & -0.0747 & 0.0149 \\
\hline 2 & -0.0263 & 0.0081 & -0.0227 & 0.0094 & -0.0331 & 0.0095 & -0.0285 & 0.0120 & -0.0067 & 0.0076 & -0.0031 & 0.0083 \\
\hline 3 & -0.0184 & 0.0078 & -0.0157 & 0.0086 & -0.0235 & 0.0090 & -0.0203 & 0.0106 & -0.0021 & 0.0061 & -0.0006 & 0.0061 \\
\hline 4 & -0.0129 & 0.0075 & -0.0109 & 0.0080 & -0.0167 & 0.0086 & -0.0147 & 0.0097 & -0.0004 & 0.0055 & 0.0002 & 0.0051 \\
\hline 5 & -0.0089 & 0.0073 & -0.0075 & 0.0076 & -0.0118 & 0.0084 & -0.0105 & 0.0090 & 0.0004 & 0.0052 & 0.0006 & 0.0047 \\
\hline 6 & -0.0060 & 0.0072 & -0.0050 & 0.0073 & -0.0082 & 0.0082 & -0.0074 & 0.0085 & 0.0008 & 0.0050 & 0.0008 & 0.0045 \\
\hline 7 & -0.0039 & 0.0070 & -0.0032 & 0.0071 & -0.0055 & 0.0081 & -0.0051 & 0.0081 & 0.0010 & 0.0049 & 0.0009 & 0.0044 \\
\hline 8 & -0.0024 & 0.0069 & -0.0019 & 0.0069 & -0.0035 & 0.0079 & -0.0034 & 0.0078 & 0.0011 & 0.0048 & 0.0009 & 0.0043 \\
\hline 9 & -0.0013 & 0.0068 & -0.0010 & 0.0067 & -0.0020 & 0.0078 & -0.0021 & 0.0075 & 0.0011 & 0.0048 & 0.0009 & 0.0042 \\
\hline 10 & -0.0004 & 0.0067 & -0.0003 & 0.0065 & -0.0009 & 0.0077 & -0.0011 & 0.0073 & 0.0011 & 0.0047 & 0.0009 & 0.0041 \\
\hline 11 & 0.0002 & 0.0066 & 0.0002 & 0.0064 & -0.0001 & 0.0076 & -0.0004 & 0.0071 & 0.0011 & 0.0046 & 0.0009 & 0.0041 \\
\hline 12 & 0.0006 & 0.0065 & 0.0006 & 0.0063 & 0.0005 & 0.0075 & 0.0002 & 0.0070 & 0.0011 & 0.0046 & 0.0009 & 0.0040 \\
\hline 13 & 0.0009 & 0.0064 & 0.0008 & 0.0062 & 0.0009 & 0.0073 & 0.0006 & 0.0068 & 0.0011 & 0.0045 & 0.0009 & 0.0040 \\
\hline 14 & 0.0011 & 0.0063 & 0.0010 & 0.0061 & 0.0013 & 0.0072 & 0.0009 & 0.0067 & 0.0011 & 0.0044 & 0.0009 & 0.0039 \\
\hline 15 & 0.0013 & 0.0063 & 0.0012 & 0.0060 & 0.0015 & 0.0071 & 0.0011 & 0.0066 & 0.0011 & 0.0044 & 0.0009 & 0.0039 \\
\hline 16 & 0.0014 & 0.0062 & 0.0013 & 0.0059 & 0.0017 & 0.0071 & 0.0013 & 0.0065 & 0.0010 & 0.0043 & 0.0009 & 0.0038 \\
\hline 17 & 0.0015 & 0.0061 & 0.0013 & 0.0058 & 0.0018 & 0.0070 & 0.0014 & 0.0064 & 0.0010 & 0.0043 & 0.0008 & 0.0038 \\
\hline 18 & 0.0016 & 0.0060 & 0.0014 & 0.0058 & 0.0019 & 0.0069 & 0.0015 & 0.0063 & 0.0010 & 0.0042 & 0.0008 & 0.0037 \\
\hline 19 & 0.0016 & 0.0059 & 0.0014 & 0.0057 & 0.0020 & 0.0068 & 0.0016 & 0.0062 & 0.0010 & 0.0041 & 0.0008 & 0.0037 \\
\hline 20 & 0.0016 & 0.0058 & 0.0014 & 0.0056 & 0.0020 & 0.0067 & 0.0016 & 0.0061 & 0.0010 & 0.0041 & 0.0008 & 0.0036 \\
\hline 21 & 0.0016 & 0.0058 & 0.0014 & 0.0055 & 0.0020 & 0.0066 & 0.0016 & 0.0061 & 0.0010 & 0.0040 & 0.0008 & 0.0036 \\
\hline 22 & 0.0016 & 0.0057 & 0.0014 & 0.0055 & 0.0020 & 0.0065 & 0.0017 & 0.0060 & 0.0010 & 0.0040 & 0.0008 & 0.0035 \\
\hline 23 & 0.0016 & 0.0056 & 0.0014 & 0.0054 & 0.0020 & 0.0064 & 0.0017 & 0.0059 & 0.0010 & 0.0039 & 0.0008 & 0.0035 \\
\hline 24 & 0.0016 & 0.0055 & 0.0014 & 0.0053 & 0.0020 & 0.0063 & 0.0017 & 0.0058 & 0.0009 & 0.0039 & 0.0008 & 0.0034 \\
\hline
\end{tabular}



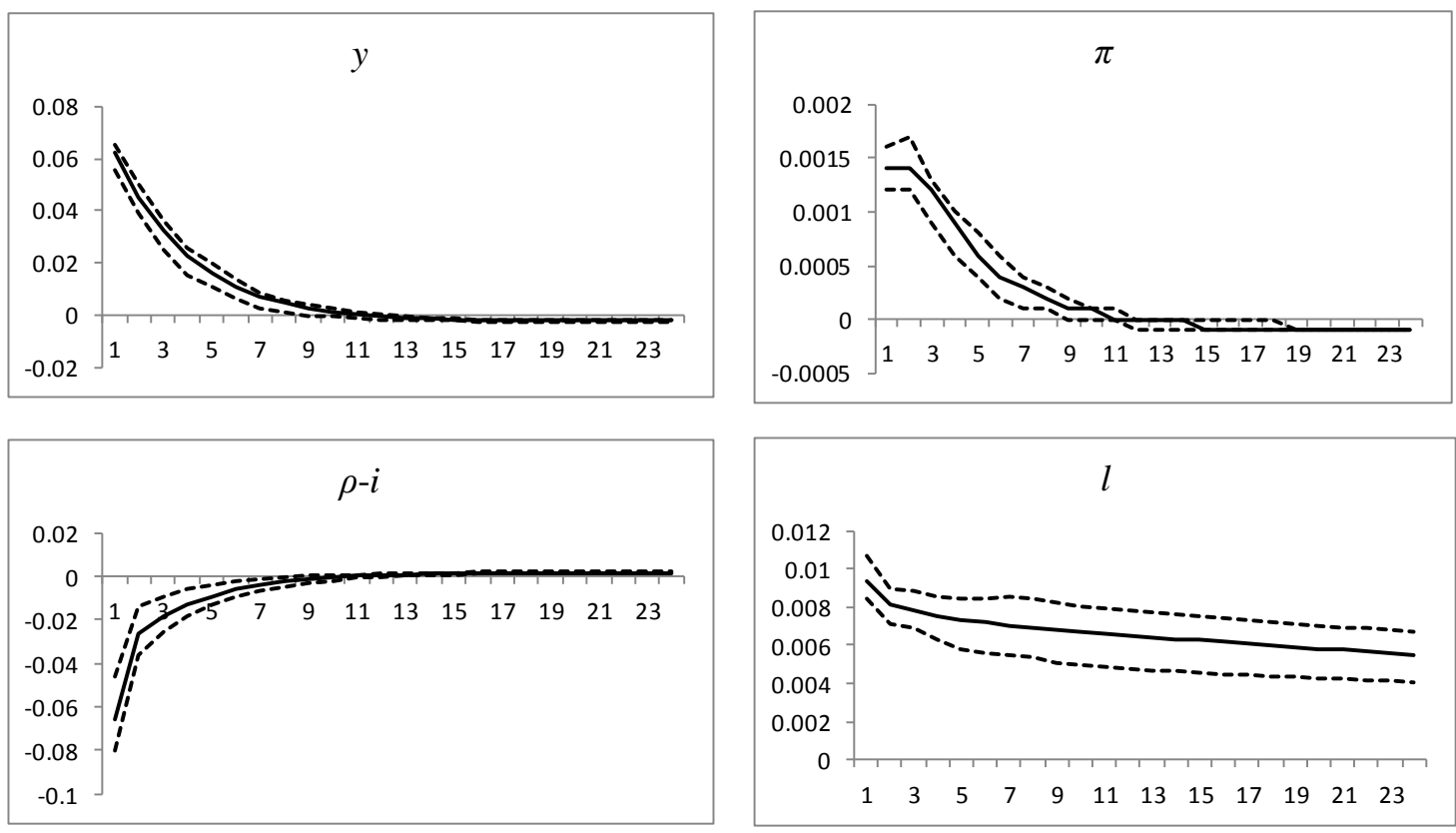

Figure 1-1. Impulse response functions: $l_{a a}$ (all banks' loans to all enterprises)
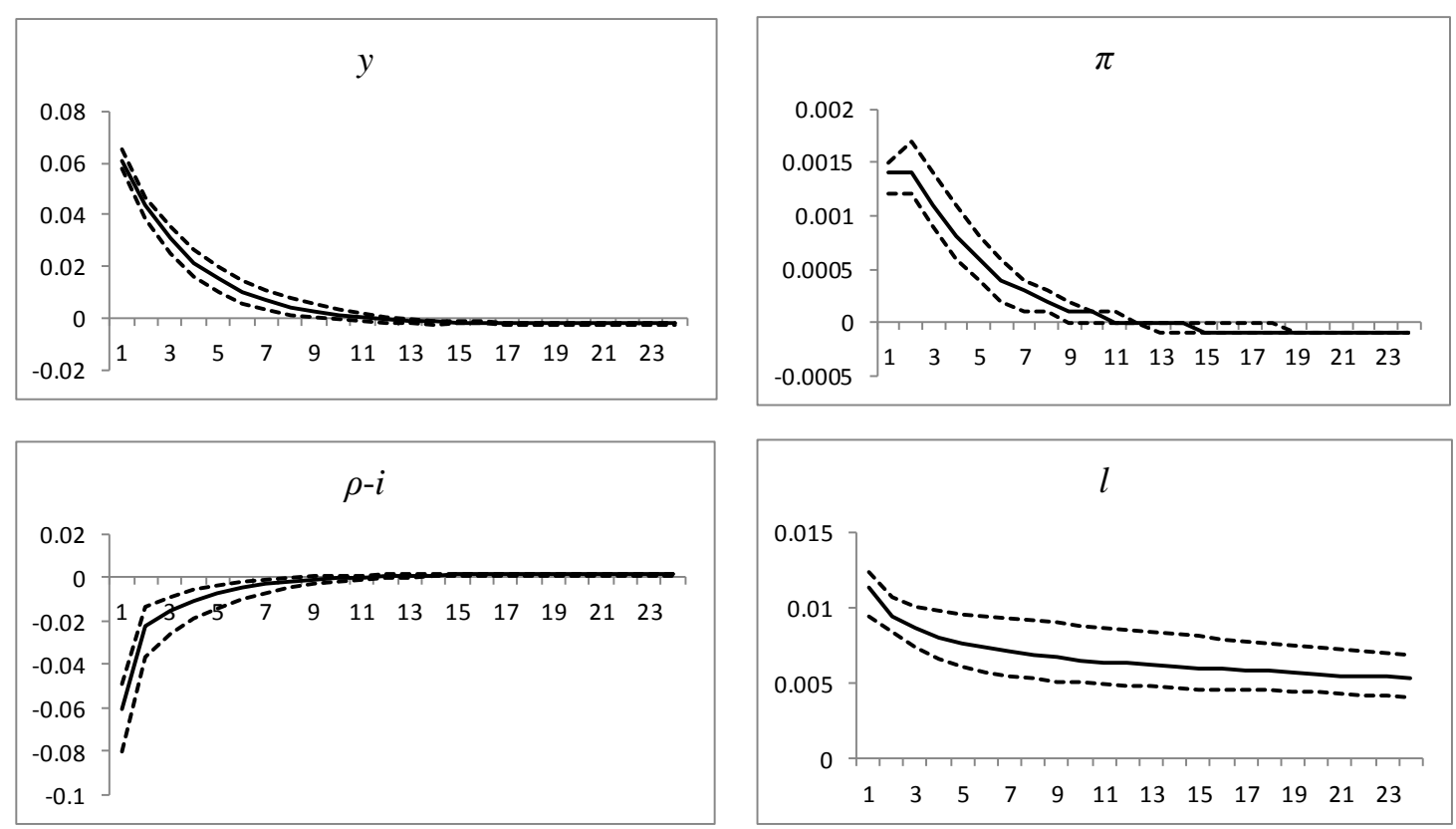

Figure 1-2. Impulse response functions: $l_{a s}$ (all banks' loans to SMEs) 

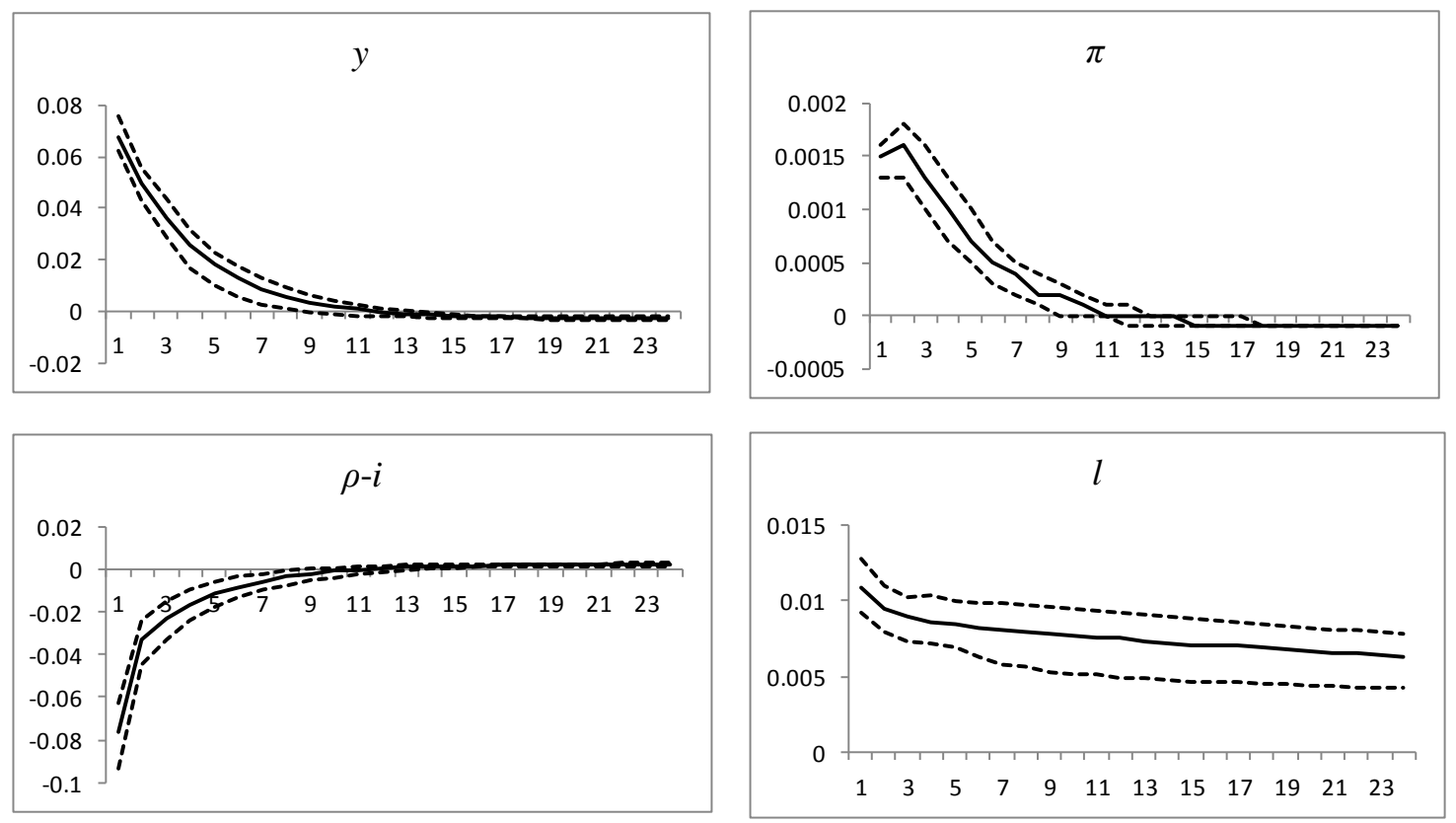

Figure 1-3. Impulse response functions: $l_{c a}$ (City banks' loans to all enterprises)
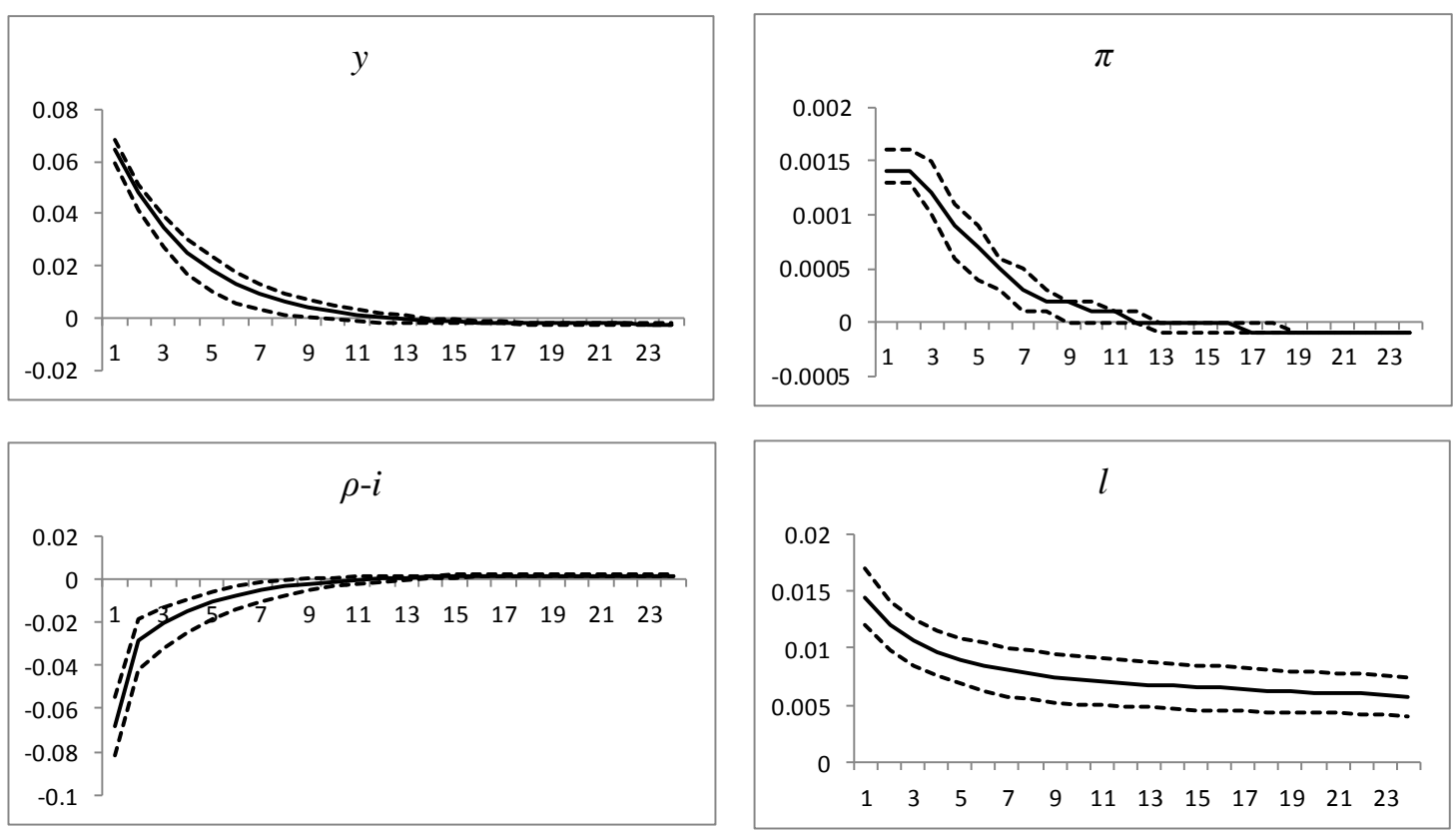

Figure 1-4. Impulse response functions: $l_{c s}$ (City banks' loans to SMEs) 

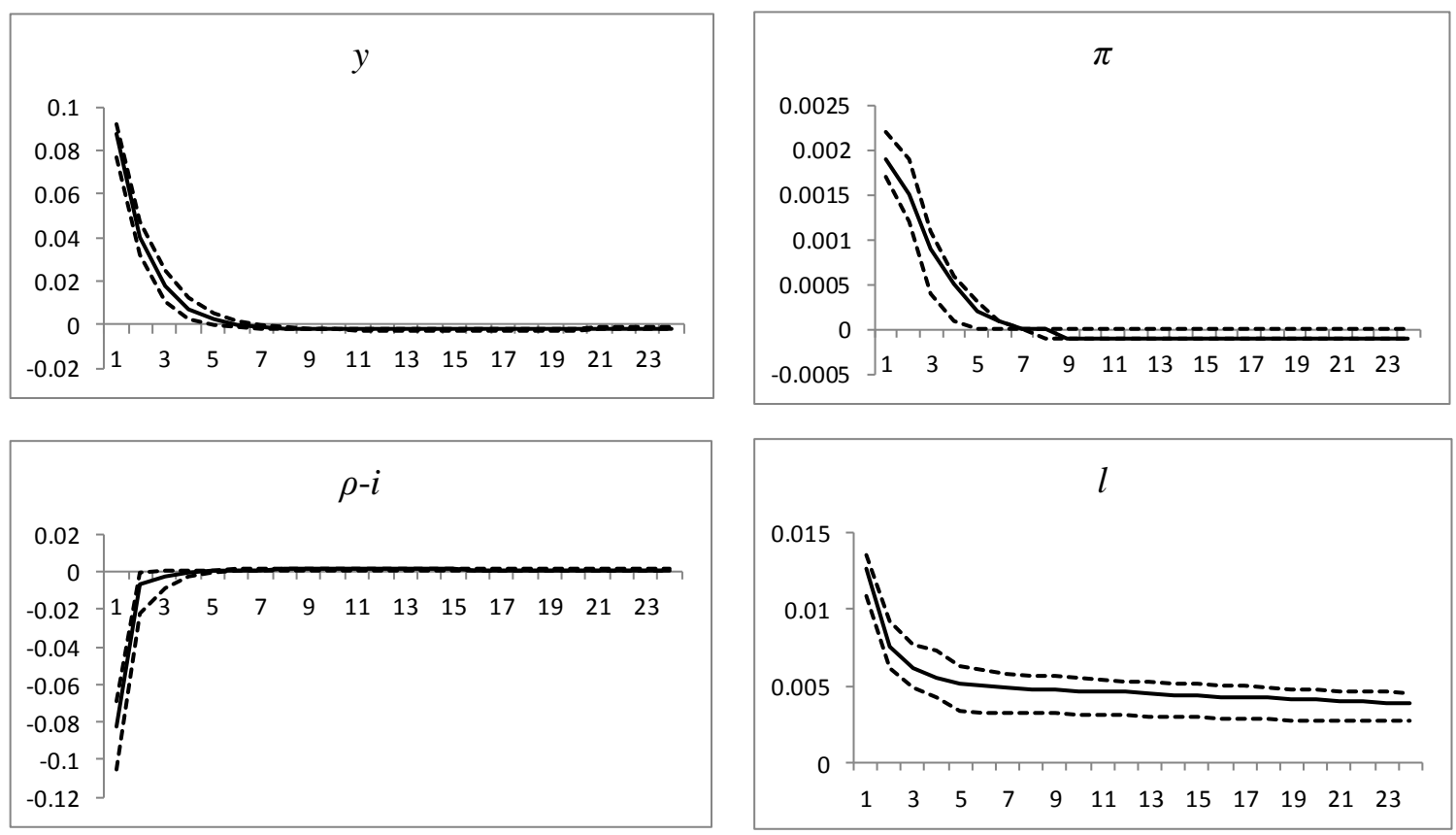

Figure 1-5. Impulse response functions: $l_{r a}$ (Regional banks' loans to all enterprises)
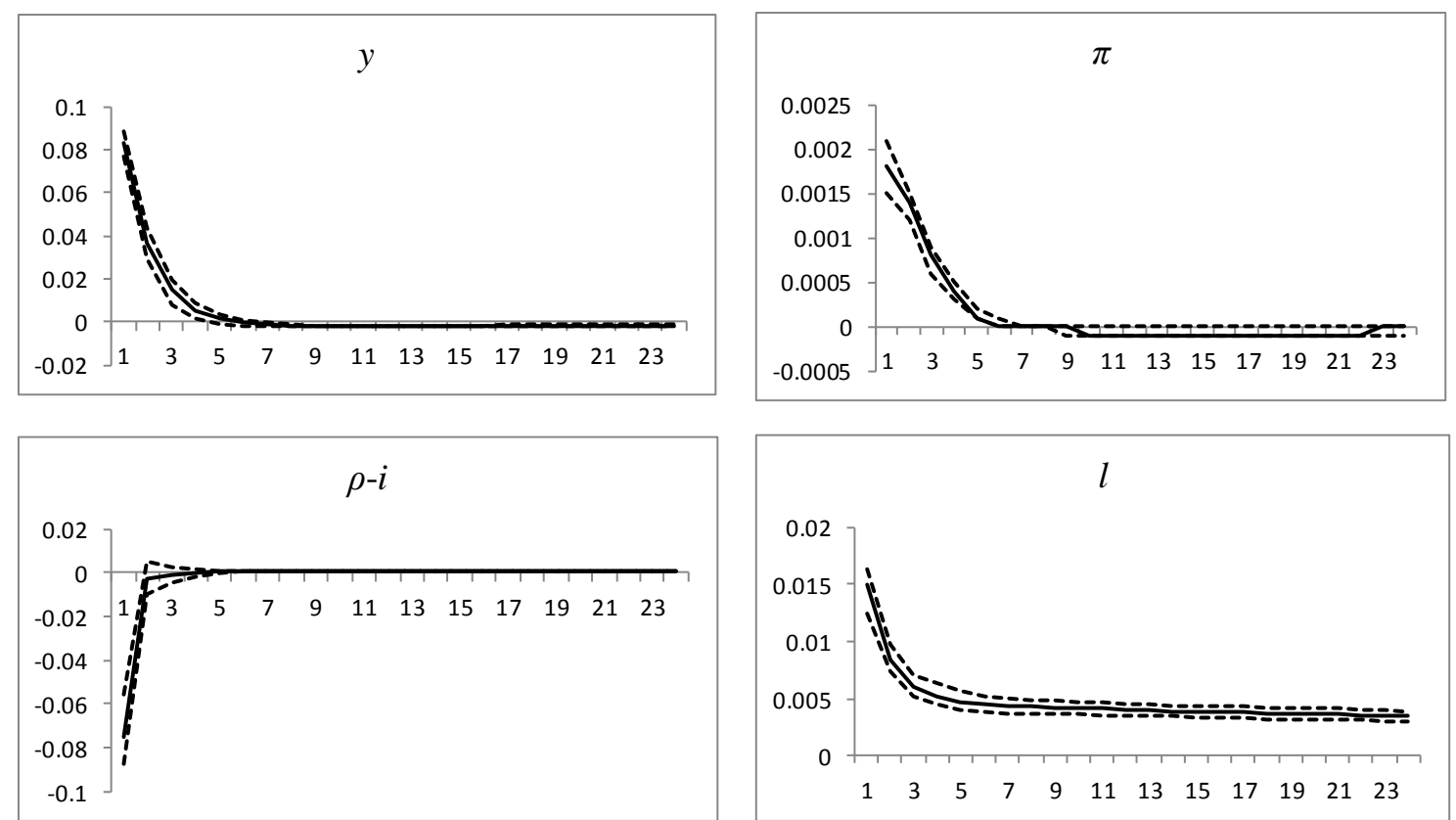

Figure 1-6. Impulse response functions: $l_{r s}$ (Regional banks' loans to SMEs) 
Table 5. Variance Decompositions

\begin{tabular}{|c|c|c|c|c|c|c|}
\hline & & & $l_{a a}$ & & & \\
\hline & $\varepsilon_{y}$ & $\varepsilon_{\pi}$ & $\varepsilon_{d d}$ & $\varepsilon_{l d}$ & $\varepsilon_{l s}$ & $\varepsilon_{r s}$ \\
\hline$y$ & 0.00 & 0.69 & 0.04 & 0.39 & 39.72 & 59.15 \\
\hline$\pi$ & 0.00 & 44.87 & 0.02 & 0.16 & 16.59 & 38.36 \\
\hline$\rho-\boldsymbol{i}$ & 0.09 & 0.05 & 29.95 & 0.63 & 64.24 & 5.05 \\
\hline \multirow[t]{3}{*}{$l$} & 0.00 & 16.25 & 0.03 & 10.44 & 9.92 & 63.36 \\
\hline & & & $l_{\text {as }}$ & & & \\
\hline & $\varepsilon_{y}$ & $\varepsilon_{\pi}$ & $\varepsilon_{d d}$ & $\varepsilon_{l d}$ & $\varepsilon_{l s}$ & $\varepsilon_{r s}$ \\
\hline$y$ & 0.00 & 0.71 & 0.04 & 0.43 & 40.14 & 58.67 \\
\hline$\pi$ & 0.00 & 46.98 & 0.02 & 0.17 & 16.21 & 36.62 \\
\hline$\rho-i$ & 0.09 & 0.04 & 30.48 & 0.69 & 64.08 & 4.61 \\
\hline \multirow[t]{3}{*}{$l$} & 0.00 & 15.43 & 0.02 & 10.66 & 12.26 & 61.63 \\
\hline & & & $l_{c a}$ & & & \\
\hline & $\varepsilon_{y}$ & $\varepsilon_{\pi}$ & $\varepsilon_{d d}$ & $\varepsilon_{l d}$ & $\varepsilon_{l s}$ & $\varepsilon_{r s}$ \\
\hline$y$ & 0.00 & 0.56 & 0.05 & 0.51 & 41.67 & 57.21 \\
\hline$\pi$ & 0.00 & 40.77 & 0.02 & 0.23 & 18.81 & 40.17 \\
\hline$o-i$ & 0.07 & 0.05 & 27.78 & 0.81 & 65.54 & 5.76 \\
\hline \multirow[t]{3}{*}{$l$} & 0.00 & 12.62 & 0.03 & 13.14 & 11.27 & 62.94 \\
\hline & & & $l_{c s}$ & & & \\
\hline & $\varepsilon_{y}$ & $\varepsilon_{\pi}$ & $\varepsilon_{d d}$ & $\varepsilon_{l d}$ & $\varepsilon_{l s}$ & $\varepsilon_{r s}$ \\
\hline$y$ & 0.00 & 0.62 & 0.04 & 0.55 & 41.08 & 57.71 \\
\hline$\pi$ & 0.00 & 43.44 & 0.02 & 0.23 & 17.45 & 38.86 \\
\hline$o-i$ & 0.08 & 0.04 & 29.61 & 0.87 & 64.67 & 4.73 \\
\hline \multirow[t]{3}{*}{$l$} & 0.00 & 11.87 & 0.01 & 12.09 & 13.92 & 62.10 \\
\hline & & & $l_{r a}$ & & & \\
\hline & $\varepsilon_{y}$ & $\varepsilon_{\pi}$ & $\varepsilon_{d d}$ & $\varepsilon_{l d}$ & $\varepsilon_{l s}$ & $\varepsilon_{r s}$ \\
\hline$y$ & 0.00 & 0.63 & 0.06 & 0.28 & 42.50 & 56.53 \\
\hline$\pi$ & 0.00 & 45.93 & 0.03 & 0.13 & 19.68 & 34.23 \\
\hline$o-i$ & 0.07 & 0.03 & 33.96 & 0.40 & 60.61 & 4.93 \\
\hline \multirow[t]{3}{*}{$l$} & 0.00 & 24.26 & 0.08 & 12.41 & 17.66 & 45.59 \\
\hline & & & $l_{r s}$ & & & \\
\hline & $\varepsilon_{y}$ & $\varepsilon_{\pi}$ & $\varepsilon_{d d}$ & $\varepsilon_{l d}$ & $\varepsilon_{l s}$ & $\varepsilon_{r s}$ \\
\hline$y$ & 0.00 & 0.64 & 0.04 & 0.36 & 41.94 & 57.01 \\
\hline$\pi$ & 0.00 & 46.27 & 0.02 & 0.16 & 19.14 & 34.41 \\
\hline$\rho-i$ & 0.08 & 0.03 & 34.13 & 0.52 & 60.66 & 4.59 \\
\hline$l$ & 0.00 & 21.55 & 0.04 & 13.55 & 19.03 & 45.84 \\
\hline
\end{tabular}

\section{Conclusions}

In this paper, we investigate empirically whether the bank lending channel operated in Japan. We focus on the differential effects of quantitative easing monetary policy regardless of bank and firm size. We extend Bernanke and Blinder's (1988) model to endogenize the price level (inflation rate) and estimate it using the Bayesian estimation method.

Our estimation results show that with respect to bank lending rate, the semi-elasticities of loan supply are larger than those of loan demand. This means that the loan supply curve is flatter in the $\rho-l$ plane; thus, following an increase in loan supply (the loan supply curve shifts to the right), a larger decline in bank lending rate is required to stimulate loan demand. We also find that with respect to bank lending rate, the semi-elasticities of both loan demand and loan supplies are almost the same regardless of bank and enterprise size.

Our Bayesian impulse response function analyses show that following a quantitative easing monetary policy shock, the lending of banks increases whereas the spread declines, which is evidence of the bank lending channel. Moreover, the spreads decline more largely, while loans increase more slightly for loans to all enterprises. This means that a quantitative easing monetary policy shock stimulates the loan demand of SMEs in larger magnitude.

From our variance decomposition analyses, we find that while a large proportion of forecast error variance in bank loans is explained by monetary policy shock, a large proportion of forecast error variance in the spread is explained by loan supply shock. These results are also evidence of the bank lending channel.

However, we find no obvious evidence that the loans of smaller banks and loans to smaller firms are more sensitive to monetary policy. Especially, a smaller proportion of forecast error variance for loans of Regional banks is explained by monetary policy shock and a larger proportion of forecast error variance of loans to SMEs is explained by the loan 
supply shock compared to that of loans to all enterprises, implying that bank loans to SMEs are more constrained by the supply side.

\section{References}

An, S., \& Schorfheide, F. (2007). Bayesian analysis of DSGE models. Econometric Reviews, 26(2-4), $113-172$.

Bernanke, B. S., \& Blinder, A. S. (1988). Credit, money, and aggregate demand. American Economic Review Papers and Proceedings, 78(2), 435-439.

Bernanke, B. S., \& Blinder, A. S. (1992). The Federal funds rate and the channels of monetary transmission. American Economic Review, 82(4), 901-921.

Brissimis, S. N., \& Magginas, N. S. (2005). Changes in financial structure and asset price substitutability: A test of the bank lending channel. Economic Modelling, 22, 879-904.

Chiades, P., \& Gambacorta, L. (2004). The Bernanke and Blinder model in an open economy: The Italian case. German Economic Review, 5(1), 1-34. http://dx.doi.org/10.1111/j.1465-6485.2004.00092.x

Christiano, L. J., Eichenbaum, M., \& Evans, C. L. (2005). Nominal rigidities and the dynamic effects of a shock to monetary policy. Journal of Political Economy, 113(1), 1-45.

Dale, S., \& Halden, A. G. (1993) Bank behavior and the monetary transmission mechanism. Bank of England Quarterly, 33(4), 478-491.

Ehrmann, M., Gambacorta, L., Martínez-Pagés, F., Sevestre P., \& Worms, A. (2003). Financial systems and the role of banks in monetary policy transmission in the Euro area. In I. Angeloni, A. Kashyap, and B. Mojon (Eds.), Monetary Policy Transmission in the Euro Area, Cambridge University Press, 235-269. http://dx.doi.org/10.1017/cbo9780511492372.018

Fackler, J. S. (1990). Federal credit, private credit, and economic activity. Journal of Money, Credit, and Banking, 22(4), 444-464. http://dx.doi.org/10.2307/1992430

Fackler, J. S., \& Rogers, J. H. (1993). An empirical open-economy macro model with credit. Journal of Macroeconomics, 15(2), 203-224. http://dx.doi.org/10.1016/0164-0704(93)90025-h

Ford, J. L., Agung, J., Ahmed, S. S., \& Santoso, B. (2003). Bank behavior and the channel of monetary policy in Japan, 1965-1999. The Japanese Economic Review, 54(3), 275-299. http://dx.doi.org/10.1111/1468-5876.00259

Galí, J., \& Gertler, M. (1999). Inflation dynamics: A structural econometric analysis. Journal of Monetary Economics 44(2), 195-222.

Gertler, M., \& Gilchrist, S. (1993). The role of credit market imperfections in the monetary transmission mechanism: Arguments and evidence. The Scandinavian Journal of Economics, 95(1), 43-64.

Gertler, M., \& Gilchrist, S. (1994). Monetary policy, business cycles, and the behavior of small manufacturing firms. The Quarterly Journal of Economics, 109(2), 309-340.

Holtemöller, O. (2003). Further VAR evidence for the effectiveness of a credit channel in Germany. Applied Economics Quarterly, 49, 359-381.

Hülsewig, O., Winker, P., \& Worms, A. (2004). Bank lending in the transmission of monetary policy: A VECM analysis for Germany. Advances in macroeconometric modeling. Papers and Proceedings of the 3rd IWH Workshop in Macroeconometrics, 239-264. http://dx.doi.org/10.2139/ssrn.304457

Kakes, J. (2000). Identifying the mechanism: Is there a bank lending channel of monetary transmission in the Netherlands? Applied Economics Letters, 7, 63-67. http://dx.doi.org/10.1080/135048500351825

Kashyap, A. K., \& Stein, J. C. (1994). Monetary policy and bank lending. In N. G. Mankiw (Ed.), Monetary Policy, 221-261. University of Chicago Press.

Kashyap, A. K., Stein, J. C., \& Wilcox, D. W. (1993). Monetary policy and credit conditions: Evidence from the composition of external finance. American Economic Review, 83(1), 78-98.

Kimura, T, Kobayashi, H, Muranaga, J., \& Ugai, H. (2003). The effects of the increase in the monetary base on Japan's economy at zero interest rates: An empirical analysis. BIS papers 19, 276-312.

Krugman, P. R. (1998a). Japan's trap mimeo. Retrieved from http://web.mit.edu/Krugman/www/japtrap.html.

Krugman, P. R. (1998b). Further notes on Japan's liquidity trap, mimeo. http://web.mit.edu/Krugman/www/liquid.html.

Miron, J. A., Romer, C. D., \& Weil, D. N. (1994). Historical perspective on the monetary policy transmission mechanism. In N. G. Mankiw (Ed.), Monetary Policy, 263-306. University of Chicago Press. 
Oliner, S. D., \& Rudebusch, G. D. (1995). Is there a bank lending channel for monetary policy? Federal Reserve Bank of San Francisco Economic Review, 95(2), 3-20.

Oliner, S. D., \& Rudebusch, G. D. (1996). Is there a broad credit channel for monetary policy? Federal Reserve Bank of San Francisco Economic Review, 96(1), 3-13.

Peek, J., \& Rosengren, E. S. (1995). Bank lending and the transmission of monetary policy. In J. Peek and E. S. Rosengren (Eds.), Is Bank Lending Important for the Transmission of Monetary Policy? Series 39. Federal Reserve of Boston Conference, 47-68.

Ramey, V. (1993). How important is the credit channel in the transmission of monetary policy? Carnegie-Rochester Conference Series on Public Policy, 39, 1-45. http://dx.doi.org/10.1016/0167-2231(93)90001-d

Romer, C. D., \& Romer, D. H. (1990). New evidence on the monetary transmission mechanism. Brookings Papers on Economic Activity, 21, 149-214.

Ueda, K. (1993). A comparative perspective on Japanese monetary policy: Short-run monetary control and the transmission mechanism. In K. Singleton (Ed.), Japanese Monetary Policy, 7-29. University of Chicago Press.

Walsh, C. E., \& Wicox, J. A. (1995). Bank credit and economic activity. In J. Peek and E. S. Rosengren (Eds.), Is Bank Lending Important for the Transmission of Monetary Policy? Federal Reserve of Boston Conference, 83-112.

\section{Notes}

Note 1. This means that bank loans and open-market bonds are not perfect substitutes and so the Modigliani-Miller capital structure invariance proposition does not hold.

Note 2. See Kimura, Kobayashi, Muranaga, and Ugai (2003) for the recent developments in monetary policy in Japan.

Note 3. Equation (2) is derived by log-linearizing the loan supply function $L_{t}^{S}=\lambda(\rho-i) \times(1-\gamma) D_{t}$, where $\gamma$ is the required reserve ratio on deposits and $\lambda$ denotes the fraction of the bank's net of required.

Note 4. The right-hand side of equation (3) is derived by log-linearizing the bank reserve demand function $R S_{t}^{S}=(\gamma+\alpha(i)) D_{t}$, where $\alpha$ denotes the fraction of reserve demand that exceeds the required reserve. $\alpha$ is decreasing in the bond rate.

Note 5. Note that we normalize the deposit interest rate as zero.

Note 6. See An and Schorfheide (2007) for a review of Bayesian methods for estimation of the DSGE model.

Note 7. Trust banks are not included.

Note 8. Strictly speaking, the semi-elasticities of loan supply are slightly larger for loans to all enterprises than for SMEs.

\section{$(c)$ EY}

This work is licensed under a Creative Commons Attribution 3.0 License. 